\title{
Utilisation of Indigenous Ceramic Raw Materials for the Production of Water Closet
}

\author{
Z. U. Elakhame ${ }^{1}$, Y. J. Obe ${ }^{1}$, Y. L. Shuaib-Babata ${ }^{2}$, L. K. Bankole1, O. J. Omowunmi1, \\ I. O. Ambali' ${ }^{2}$, 0. O. Akinsanya', A. J. Unachukwu'1, R. G. Adeyemo ${ }^{3}$, M. Ikusedun' ${ }^{1}$ \\ ${ }^{1}$ Federal Institute of Industrial Research, Lagos, Nigeria \\ ${ }^{2}$ Department of Materials and Metallurgical Engineering, University of Ilorin, Ilorin, Nigeria \\ ${ }^{3}$ Department of Welding and Fabrication Engineering, Gateway (ICT) Polytechnic, Saapade, Nigeria \\ Email: *ezeberu@yahoo.com
}

How to cite this paper: Elakhame, Z.U., Obe, Y.J., Shuaib-Babata, Y.L., Bankole, L.K., Omowunmi, O.J., Ambali, I.O., Akinsanya, O.O., Unachukwu, A.J., Adeyemo, R.G. and Ikusedun, M. (2020) Utilisation of Indigenous Ceramic Raw Materials for the Production of Water Closet. Journal of Minerals and Materials Characterization and Engineering, 8, 364-376.

https://doi.org/10.4236/jmmce.2020.85023

Received: March 19, 2020

Accepted: August 9, 2020

Published: August 12, 2020

Copyright $\odot 2020$ by author(s) and Scientific Research Publishing Inc. This work is licensed under the Creative Commons Attribution International License (CC BY 4.0).

http://creativecommons.org/licenses/by/4.0/

\section{(c) (i) Open Access}

\begin{abstract}
The fact is that Nigeria ceramic raw materials are underutilized as a result of inadequate information on the materials which limits the local production of water closet. The emphasis of this research was on the suitability of the physio-chemical properties of the abundant locally sourced ceramic raw materials from South-west Nigeria. The selected locally sourced raw materials included: kaolin, feldspar, silica and ball clay. The Physical properties carried out on the specimens produced include chemical analysis, shrinkage, porosity, bulk density, modulus of rupture, plasticity and viscosity. The physical property tests were done in accordance with (ASTM C). Standard and the chemical composition were identified by AAS spectrometer. However, the ratio of kaolin, feldspar, quartz and ball clay was varied in five major formulation represented as A, B, C, D and E. The clay, kaolin, quartz and feldspar used in this study were found to belong to alumina-silicate group suitable for the production of standard water closet. The samples' properties met the required standards; hence, the materials were found suitable for production of water closet of acceptable standards. Composition A specimen gives the most suitable proportions for the production of water closet at $40 \%$ of kaolin, $25 \%$ of feldspar, $10 \%$ of quartz and $25 \%$ of ball clay respectively.
\end{abstract}

\section{Keywords}

Ceramics Materials, Characterization, Mould, Slip-Cast, Water-Closet

\section{Introduction}

This water closet is a sanitary fixture used primarily for the disposal of human excrement and urine, often found in a small room referred to as toilet, bathroom 
or lavatory. A system for dealing with excrement is necessary in every human community, and the need becomes more pressing in more densely populated areas [1].

In Nigeria at earlier period, there had been problems of open defecation which dates back to when people living in the rural communities made use of dump sites and bushes to relieve themselves. With colonisation, pit latrines and much later, closed water system came into existence [2].

The ceramic industries in Nigeria have not been enterprising when judged from available data as sourced from the Raw Materials Research and Development Council (RMRDC), Abuja. There is abundance of ceramics raw materials locally; therefore, the problem is not the scarcity of raw materials, but inadequate technology, because the ceramics industry can be sustained on low level technology [2] [3]. Six problems were however identified to be militating against Nigeria ceramics industry in the past and these included unfavorable industrial climate, entrepreneurial attitude, lack of skilled manpower, neo-colonial acculturation, lack of inter-disciplinary co-operation and poor management.

Due to the complex nature of water closet and man's needs when it comes to convenience, [4] postulated that water closet needs to have these three qualities; it needs to be a flushing engine, water-proof, clean and sanitary. The need to study this, is as a result of the weight of people sitting on it. Vitreous china, as it turns outperforms well at all these requirements. [5] further stated that vitreous china (porcelain ceramics) water closets are made from ball clay, kaolin, quartz, feldspar and water.

There is abundance of feldspar and quartz at Lanlate in Ogun state, Ijero in Ekiti state, and Oshogbo in Osun state respectively; quartz at Ijero in Ekiti state, Badagry and Epe in Lagos state and Igbokoda in Ondo state [5] [6].

The problems associated with the production, uses and patronage of water closet in Nigeria are not based on the unavailability of raw materials. Therefore, there is abundance of ceramics raw materials in Nigeria [7].

The lack of a developed raw materials support industry and absence of skilled manpower implied that local ceramics curriculum is skewed more towards fine art as sometimes ceramics designers are employed as ceramics engineers, ceramics scientists or technologists.

The uses and patronage of ceramics water closet are high in Nigeria; thus local demand for ceramics products is very high considering our population of over one hundred and seventy million, yet the supply is met through importation [7].

Research shows that Nigeria ranks $13^{\text {th }}$ among the world's consumers of ceramics products, mostly ceramics water closet [8]. In addition, about fifty containers of ceramics products come into the country daily as reported by Manufacturers Association of Nigeria (MAN) [9].

Therefore, this research focused on the suitability and utilization of local ceramics raw materials from Southwest Nigeria in compounding workable recipe, for the production of water closet through a production process that can be car- 
ried out at a small scale or even at cottage level.

\section{Materials and Methods}

\subsection{Materials}

The raw materials used in this study are kaolin, feldspar, silica sand and ball clay sourced from Ijero in Ekiti, Sangotedo in Lagos and Magboro in Ogun state respectively. Raw materials specimens from their deposit for production of water closet in solid forms are shown in Figure 1.

\subsection{Methods}

\subsubsection{Chemical Analysis}

The chemical compositions of the representative samples of the kaolin, quartz, feldspar and ball clay were analyzed and determined, using Atomic Absorption Spectrometer (AAS) UNICAM 929.

\subsubsection{Preparation of Materials \\ Clay materials}

To remove debris and other unwanted materials in the Clay and Kaolin samples, the clay and kaolin were soaked in water for five (5) days, sieved with a mesh of $250 \mu \mathrm{m}$ and dried at room temperature for one week. Meanwhile, the dried specimens in addition with Quartz and Feldspar were crushed using Hammer Milling Machine (Model; 000T, PUISSANE; 1.5KV, S/N; 13634), milled into fine size particles using ball milling machine (Model; 87002 .... Limoges-France, Type; A50 - 43), and then sieved with a Vibro-Sieve (Model; Fritsch GmbH, D-55743.1 Dar-Oberstein Germany) into $100 \mu \mathrm{m}$ particles size.

In forming the raw materials mixed for the production of the specimens, quartz and felspar were added to the clay and kaolin materials at different proportion as presented in Table 1. Hydraulic pressure of about $70 \mathrm{Mpa}$ was used to compact the powdered ingredients specimen's mixed particles into circular-shaped mould of diameter $30 \mathrm{~mm}$ and length $70 \mathrm{~mm}$. The specimens under pressurized press were held for about a week at room temperature and then dried for $48 \mathrm{hrs}$ at $100^{\circ} \mathrm{C}$ in an electric oven. Finally, the dried specimens were charged into an electric furnace (Thermolyne, 46200) before fired at $1300^{\circ}$. Below are the specimens produced for characterization. Shown in Figure 2 is the specimens produced for characterization of the sanitary ware.

Table 1. Proportion of ball clay, kaolin, feldspar and silica in forming the raw mixes for the production of water closet (Formulation A - E).

\begin{tabular}{cccccc}
\hline Batch Body Compositions & \multicolumn{5}{c}{ Composition (\%) } \\
\hline & A & B & C & D & E \\
\hline Kaolin & 40 & 40 & 45 & 50 & 55 \\
Feldspar & 25 & 30 & 30 & 30 & 30 \\
Quartz & 10 & 20 & 20 & 20 & 5 \\
Ball Clay & 25 & 10 & 5 & 0 & 10 \\
\hline
\end{tabular}




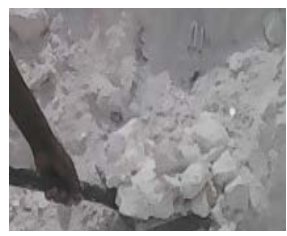

(a) Kaolin

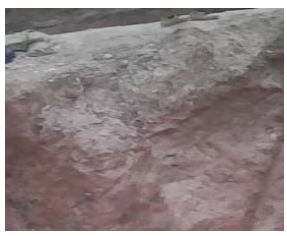

(b) Feldspar

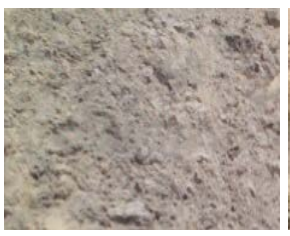

(c) Quartz

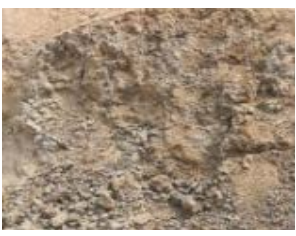

(d) Ball clay

Figure 1. Samples of the raw materials used for the production of water closet in solid form.

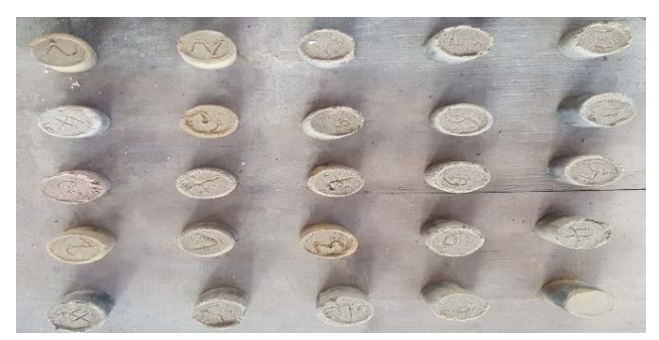

Figure 2. Produced specimens for characterization.

\subsubsection{Modelling Process}

Here, the desired shape of the model was carefully built with lump of clays shaped into a rectangle, having a rectangular dimension of $35 \times 25(\mathrm{~cm})$ shaped into an oblong shape. Another lump of clay was molded into a dimension of 25 $\times 15(\mathrm{~cm})$ shape, and then finally, shaped into a cylindrical form. The oblong shaped clay in a proportion such that there was an extruding part of $8 \mathrm{~cm}$ toward the wider part of the oblong formed clay.

Therefore, dimension of $25 \times 15(\mathrm{~cm})$ shape of the angular projection of the extruding tail-like jointed at $45^{\circ}$ and $35^{\circ}$. The whole formed object was aliened together at $90^{\circ}$ oblong shaped part ta $45^{\circ}$ and $35^{\circ}$ extruding tail like section all compacted together projecting a toilet water closet flushing system. Figure 3 shows a completed three dimensional model projection.

\subsubsection{Mould Making Process}

The model was systematically built into number of pieces mould required for casting. Profile was also constructed to create cavities in their fixed position to form a profile lines round the model using clay slab and clay box to build round the whole section of the mould.

Meanwhile, domes of clay are created at the four edge of the mould to form a hollow halve of the notches or keys in the plaster. The internal part was rubbed with engine oil to permit easy separation of the model from the plaster mould and then poured the prepared plaster slip into the vacuum created between the retention wall and the model. The plaster slip is stirred to eliminate the formation of air bubbles. On setting, the walls are dismantled for both sides to be created. Figure 4(a) \& Figure 4(b) shows the cuttle built round sectioned model and pouring POP slip for cast mould.

\subsubsection{Slip Casting Process}

The surface of the mould was thoroughly cleaned from the possible trace of dust 
and assembled both two pieces firmly tied together with rubber bands. All the crevices between the two mould pieces were sealed up with wet clay material. The prepared slip was stirred vigorously and then poured into the prepared mould for 1 hour timing was given for casting period to allow the desired thickness to develop. Topping an extra slip was done at the level of the slip in the mould reduced. Excess slip was therefore poured off and collected for subsequent use. The slip left was allowed to continue harden and it eventually shrined away from the mould and then finally removed the fettled products showed in Figure 5.

\subsubsection{Firing Process}

The produced pieces were dried for 2 weeks at ambient temperature, held overnight and then dried at $90^{\circ} \mathrm{C} \pm 100^{\circ} \mathrm{C}$ for 48 hours in an oven. Dried specimens were fired in a laboratory type electric furnace (Nabertherm, more than heat $30^{\circ} \mathrm{C}-3000^{\circ} \mathrm{C}$ ) at the rate of $5^{\circ} \mathrm{C} / \mathrm{min}$. The technological parameters values were measured after firing steps. The firing procedure used involves heating the sample at a temperature of $1000^{\circ} \mathrm{C}$, then soaked for 3 hours and naturally cooled [10]. The procedures were repeated for all the formulations.

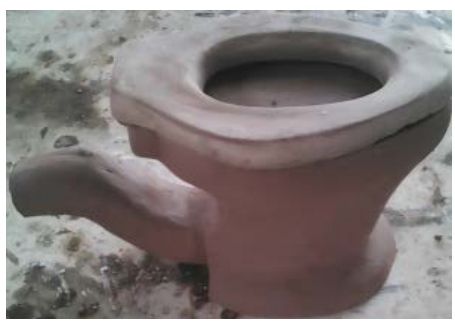

Figure 3. Completed three dimensional model projection.

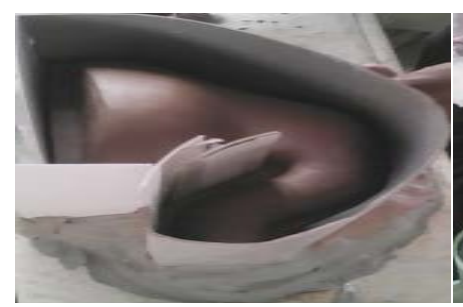

(a)

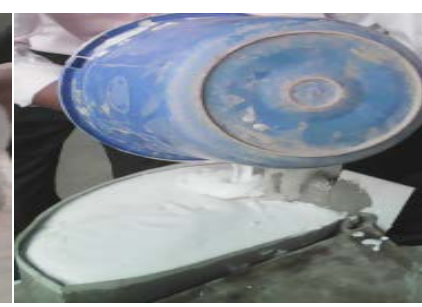

(b)

Figure 4. (a) Cuttle built round sectioned model; (b) Pouring POP slip for cast mould.

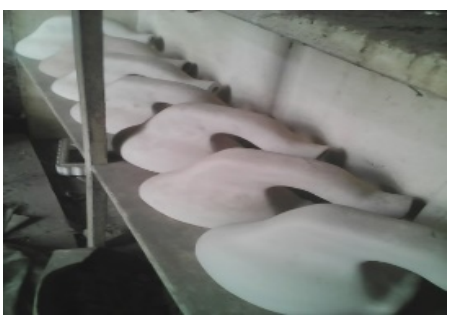

Figure 5. Fettled products. 


\subsubsection{Glazing}

After the bisque firing, the wares were prepared for glazing. Dipping method of glaze application was used to apply the glaze onto the wares. Then, the wares were loaded into the kiln for glaze firing. Precautions were taken to avoid wares that had been glazed touching one another during loading before glaze firing. Figure 6, shows from dipping to final glazing wares.

\subsection{Determination of the Specimens Properties}

Some properties of the material mixed (moulded specimens) were tested for proper evaluation of their suitability. The properties include fired shrinkage, apparent porosity, bulk density, porosity and compressive strength and chemical composition. For the products to be in compliance with National and International Standards, these properties were evaluated using various national and international test procedures and standards.

\subsubsection{Porosity}

Porosity of the samples was determined using ASTM JISD4418-1996 guidelines by soaking the sample in a bath of water at $100^{\circ} \mathrm{C}$ for 8 hours. Mass of each of the samples before and after soaking were determined (in $\mathrm{mg}$ ) and recorded. Porosity of the samples were then determined using Equation (1).

$$
\operatorname{Porosity}(\mathrm{p})=\frac{M_{1}-M_{2}}{p V} \times 100
$$

where $M_{1}$ is the mass $(\mathrm{g})$ of sample before soaking, $M_{2}$ is the mass (g) of sample after soaking water, $p$ is the density.

\subsubsection{Apparent Porosity (AP) and Bulk Density (BD)}

The apparent porosity of the samples was also determined in accordance with JIS D 4418 - 1996. Cylindrical samples of $(30 \times 70 \mathrm{~mm})$ dimension were used. The samples dried weight in air $\left(W_{d a}\right)$, soaked weight $\left(W_{s a}\right)$ and the saturated $\left(W_{s w}\right)$ of each sample were determined. The apparent porosity $(\mathrm{Pa})$ and bulk density (BD) of each brick was determined using the relationships in Equation (2) and (3) respectively.

$$
\begin{gathered}
\operatorname{Apparent} \operatorname{Porosity}(\mathrm{Pa})=\frac{W_{s a}-W_{d a}}{W_{s a}-W_{s w}} \times 100 \\
\text { Bulk density }(\mathrm{BD})=\frac{W_{d a}}{W_{s a}-W_{s w}}
\end{gathered}
$$

\subsubsection{Modulus of Rupture (MOR)}

The compressive property test was conducted on the samples using Testometeric Universal Testing Machine [TUF-C-1000 KN (SI)] as specified by the MS ISO (part 6): 2006 standard. Samples were loaded gradually in compression until the sample failed to offer further resistance to deformation which was indicated by the sample fracture. 


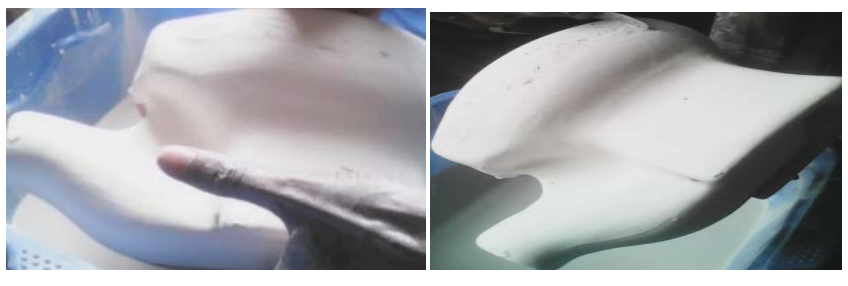

(a) Dipping

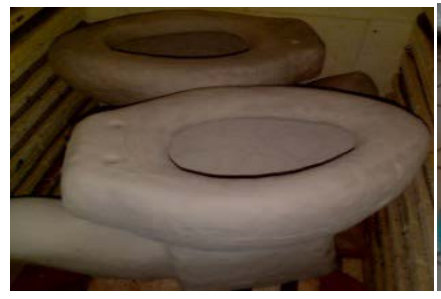

(c) Kiln loading (b) Uniform surface

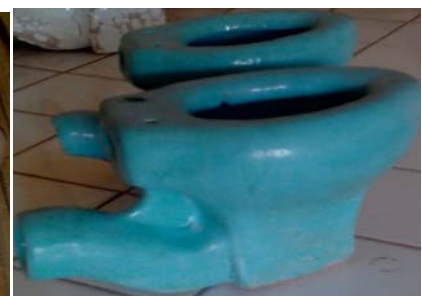

(d) Final glazed wares

Figure 6. Developed products from dipping to final glazed ware.

\subsubsection{Fired Shrinkage}

The shrinkage properties of the samples were determined by measuring both the green and fired dimensions of the samples, using Length Comparator with Digital Indicator in accordance with the guidelines in ASTM C227/and as specified by the ISO 10545-2 standard. Both sides of the specimens were measured and the average linear shrinkage was calculated. Linear shrinkage of both side of the sample was calculated as a percentage of the original green dimension as expressed in Equation (4)

$$
\text { Linear Shrinkage }(\text { Ls })=\frac{L_{g}-L_{f}}{L_{g}} \times 100
$$

where $L_{g}$ and $L_{f}$ are green and fired length of samples respectively.

\subsubsection{Viscosity}

Viscosity of the liquid sample was determined using ASTM JISD4418-1996 guidelines by filling the volume of the funnel to a height of $30 \mathrm{~cm}$ and then released bottom cover to observe the flowing rate time (s). Viscosity of the liquid samples were then determined using Equation (5).

$$
\operatorname{Viscosity}(\mathrm{V})=\frac{V}{T}
$$

where $V$ is the volume $(\mathrm{cm})$ of the used funnel, $T$ is the time (s) rate of flowing.

\subsubsection{Plasticity}

The plasticity index of the samples was determined using ASTM International D4943. $50 \mathrm{~g}$ of clay sample was put into a container and a little amount of water added to it. The moistened clay was moulded into cylindrical shape by using cylindrical mould. The molded clay was deformed by dropping onto it from a fixed height a flat-headed plunger of know weight. The distance travelled was read from the graduated scale. The modulus of plasticity (MOP) for the clay sample was obtained from the expression: 


$$
\text { MOP }=\frac{\text { Original Height }}{\text { Deformed Height }}
$$

\section{Results and Discussion}

\subsection{Materials Chemical Composition}

The results of chemical analysis in Table 2 show the major constituents of the clays, quartz and feldspar.

It is shown in the results (Table 2) that $80 \%$ and above constituents of the clay, ball clay, quartz and feldspar were silica $\left(\mathrm{SiO}_{2}\right)$ and Alumina $\left(\mathrm{Al}_{2} \mathrm{O}_{3}\right)$. Clay possessed values of (45.85\% and $35.12 \%)$, Kaolin (46.28\% and $31.73 \%)$, feldspar (49.16\% and $34.02 \%)$ and Quartz (98.80\% and $0.30 \%)$ of silica and alumina respectively. Therefore, the kaolin, ball clay and feldspar belong to Alumino-silicate group. It is proved that high amount of silica and alumina in quartz and feldspar will aid in achieving high mechanical properties expected in ceramics composite products in line with the view of [10] [11] [12].

\subsection{Shrinkage}

Figure 7 shows the results of shrinkage test. From the results obtained so far, specimen A gives the best result at value of $5.15 \%$ with closed similar results values at specimens $\mathrm{E}, \mathrm{B}$ and $\mathrm{C}$ composition lie within standard value for water closet at value range $5 \%-10 \%[12]$.

The significant value of specimen A was as a result of $40 \%$ of Kaolin and $25 \%$ of Ball clay with low percentage presence of appreciable $\mathrm{SiO}_{2}$ and $\mathrm{Al}_{2} \mathrm{O}$ in the composition. This has proved that clays are responsible for the enhancement of shrinkage.

Table 2. The chemical compositions of all the raw minerals.

\begin{tabular}{cccccc}
\hline$S / N$ & Parameter & \multicolumn{4}{c}{ Level of Detection (\%) } \\
\hline 1 & & Clay & Kaolin & Feldspar & Quartz \\
\hline 2 & $\mathrm{SiO}_{2}$ & 45.85 & 46.28 & 49.16 & 98.80 \\
3 & $\mathrm{TiO}_{2}$ & 0.005 & 0.002 & 0.01 & $0 . .00$ \\
4 & $\mathrm{Al}_{2} \mathrm{O}_{3}$ & 35.12 & 31.73 & 34.02 & 0.30 \\
5 & $\mathrm{Fe}_{2} \mathrm{O}_{3}$ & 14.70 & 5.320 & 0.74 & 0.01 \\
6 & $\mathrm{CaO}_{5}$ & 1.400 & 5.200 & 2.87 & 0.03 \\
7 & $\mathrm{MgO}^{2}$ & 0.080 & 0.130 & 0.63 & 0.00 \\
8 & $\mathrm{Na}_{2} \mathrm{O}$ & 0.050 & 0.058 & 8.40 & 0.01 \\
9 & $\mathrm{~K}_{2} \mathrm{O}$ & 0.026 & 0.049 & 0.002 & 0.00 \\
10 & $\mathrm{MnO}$ & 0.012 & 0.005 & 0.005 & 0.00 \\
\hline
\end{tabular}




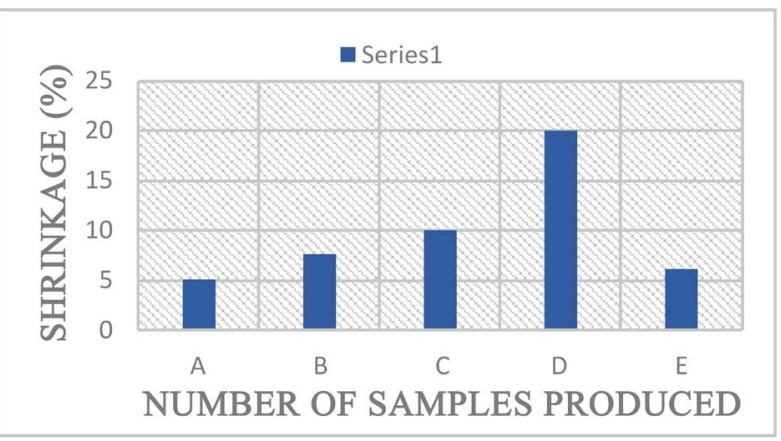

Figure 7. Average linear shrinkage values of different samples produced with varying composition.

\subsection{Porosity, Water Absorption and Bulk Density}

Figure 8 shows that specimen A gives the best lowest porosity value at $15.161 \%$. In addition to that, composition $\mathrm{B}, \mathrm{E}$ and $\mathrm{C}$ also possessed similar accepted range from $10 \%-30 \%$ [13].

This has indicated that, high percentage of kaolin and ball clay with little percentage of $\mathrm{SiO}_{2}$ and $\mathrm{Al}_{2} \mathrm{O}$ has a very strong interfacial bond on its firing behaviour that led to sealed all the pores not to give room for high value of porosity and is directly proportional to the water absorption at composition A, B, E, C and D respectively, shown in Figure 9.

Figure 10 shows the most recommended standard value of bulk density range from $2-4 \mathrm{~g} / \mathrm{cm}^{3}$ for water closet [13]. Specimens C and D composition had the lowest bulk density value of $3.10 \mathrm{~g} / \mathrm{cm}^{3}$ and $3.12 \mathrm{~g} / \mathrm{cm}^{3}$ respectively, while composition $A$ and $B$ have a higher value of $3.610 \mathrm{~g} / \mathrm{cm}^{3}$ and $3.341 \mathrm{~g} / \mathrm{cm}^{3}$ respectively. It is observed that the increased in percentage of kaolin and ball clay is directly proportional to the increased in bulk density.

\subsection{Modulus of Rupture}

Figure 11, shows that composition A specimen has the highest peak value of MOR at $5.246 \mathrm{kgF} / \mathrm{cm}^{2}$, while composition $\mathrm{E}, \mathrm{C}$ and $\mathrm{B}$ have a value that falls within the accepted range values from $4 \mathrm{kgF} / \mathrm{cm}^{2}-6 \mathrm{kgF} / \mathrm{cm}^{2}$. Moreover, it is also observed that the increased in percentage of kaolin and ball clay is directly proportional to the increased in MOR. The low percentage of $\mathrm{SiO}_{2}$ and $\mathrm{Al}_{2} \mathrm{O}$ in the raw materials component would have combined to form some considerably low temperature melting compounds, which increase the strength of the bulk composition on cooling [14].

\subsection{Plasticity and Viscosity}

The result from Figure 12 shows that the clay and kaolin have moderate plasticity as best indicated in specimen $\mathrm{A}$ composition value at $3.08 \%$. In addition to that, specimen $\mathrm{B}, \mathrm{C}$ and $\mathrm{E}$ also have the acceptable range values, except composition D specimen with lower value of $2.03 \%$. The kaolin and ball clay have a good workability, that is, it can be worked into shape. This plasticity makes it good for 
many industrial products at best specimen A but the iron oxide and it suggests that it can be used as a binder in the absence of standard binder like phosphoric acid [15].

While Figure 13 shows the average flowing rate in composition $\mathrm{E}$ specimen at $(3.08 \mathrm{~m} / \mathrm{s})$ value which actually give the best result. It was observed that composition A specimen flow slower than all the samples at a very slow rate value of $3.08 \%$. The observation here is that, the lower the percentage of kaolin and ball clay, the faster the flow of plasticity.

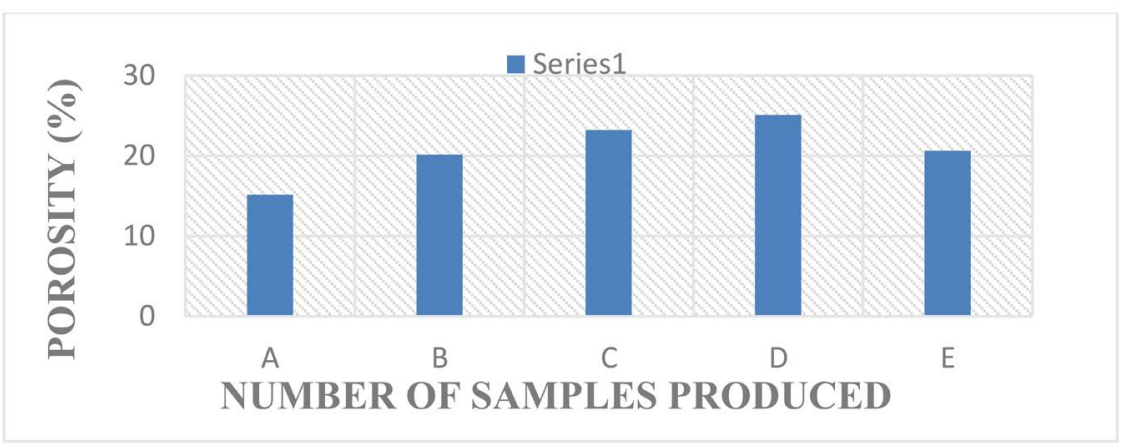

Figure 8. Average porosity values of different samples produced with varying compositions.

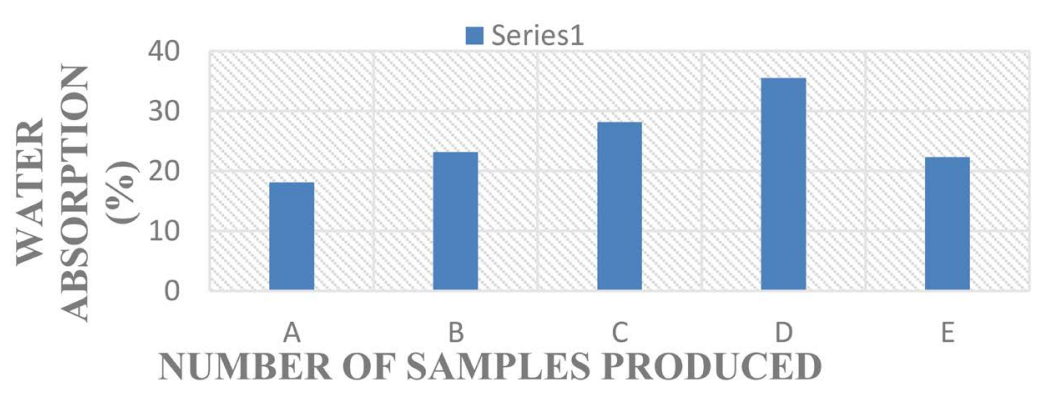

Figure 9. Average water absorption values of different samples produced with varying composition.

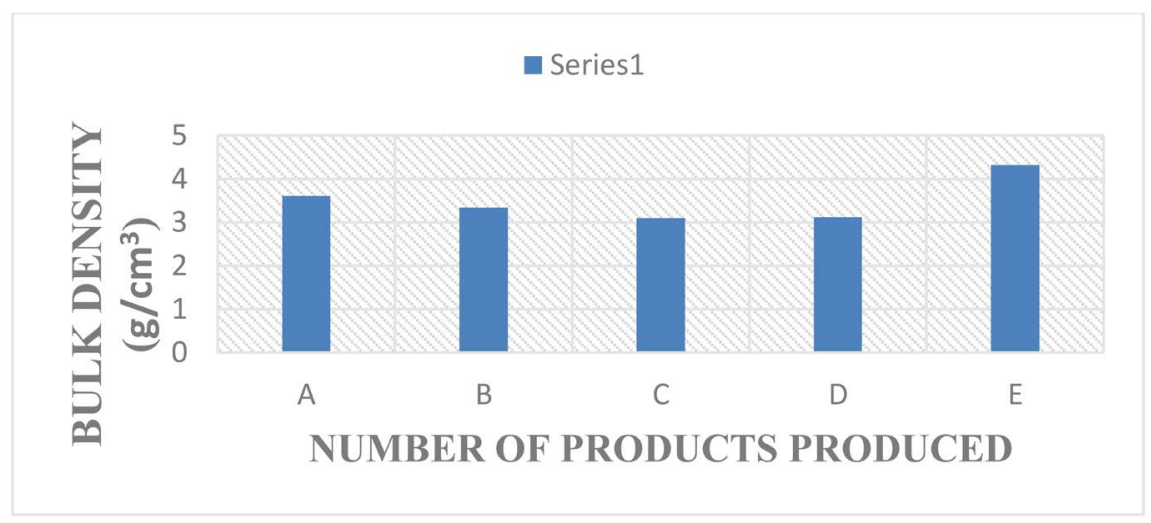

Figure 10. Average bulk density values of different samples produced with varying compositions. 


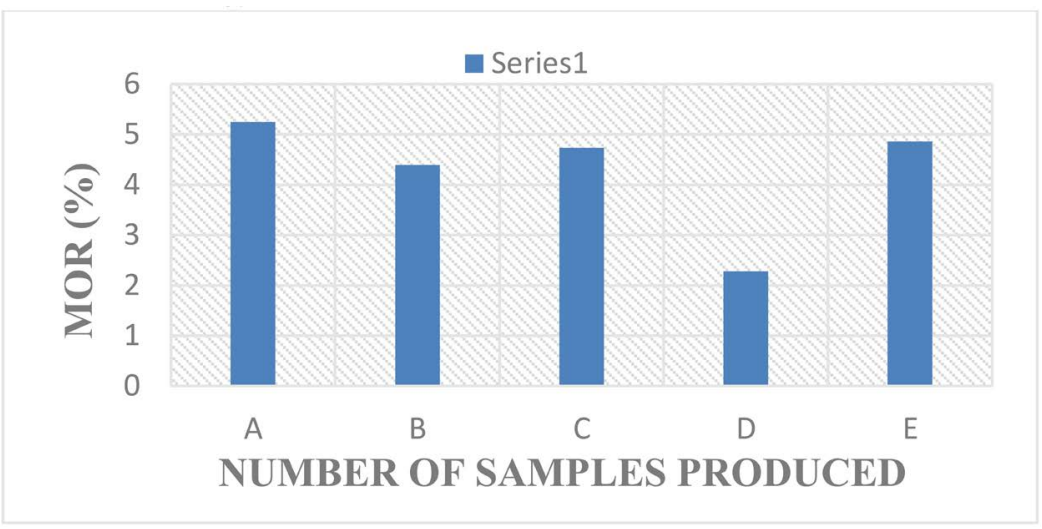

Figure 11. Average modulus of rupture values of different samples produced with varying compositions.

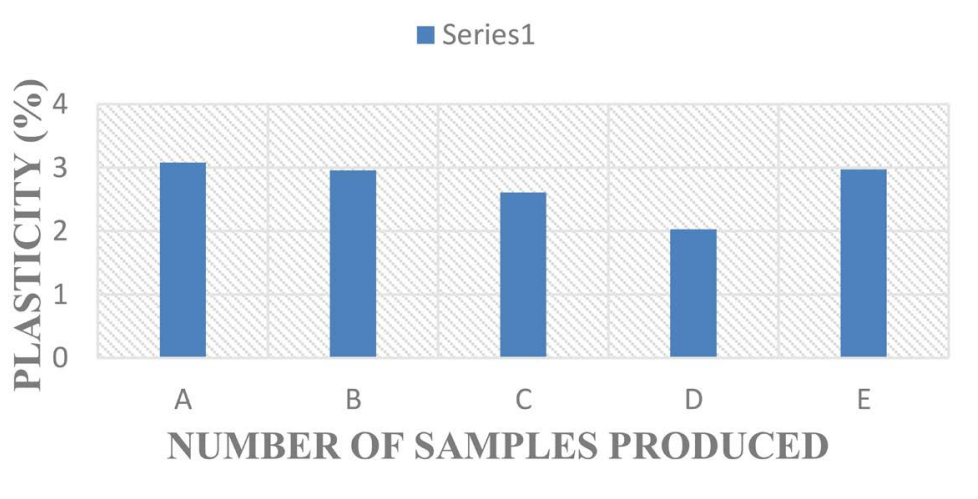

Figure 12. Average plasticity values of different samples produced with varying compositions.

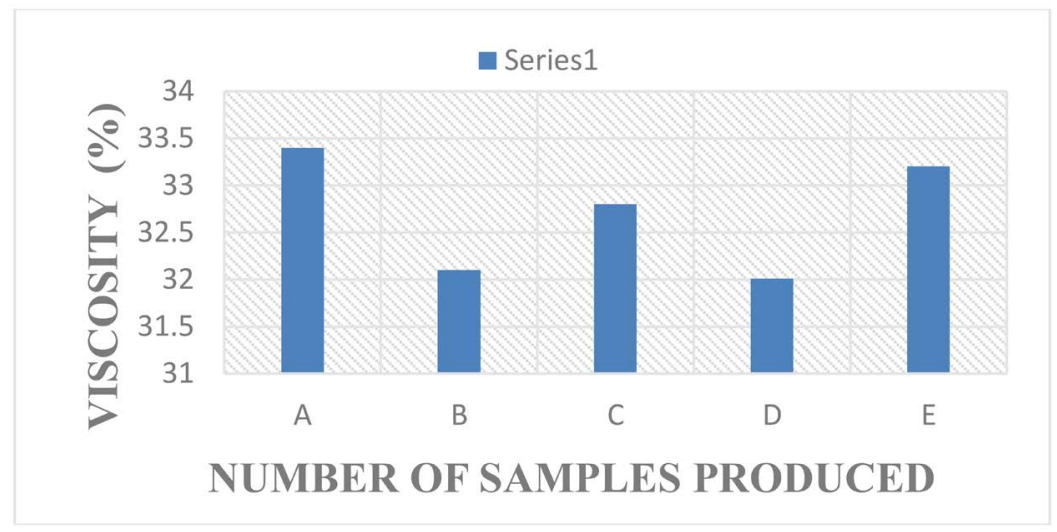

Figure 13. Average viscosity values of different samples produced with varying compositions.

\section{Conclusions}

The clay, kaolin, quartz and feldspar used in this study were found to belong to alumina-silicate group suitable for the production of standard water closet. Composition A specimen gives the most suitable proportions for the production 
of water closet at $40 \%$ of kaolin, $25 \%$ of feldspar, $10 \%$ of quartz and $25 \%$ of ball clay respectively.

Clay, silica, feldspar and ball clay were characterized to ascertain their potentials for water closet, refractory and other ceramics applications. The results obtained show that they meet the criterial for application as water closet raw materials in the entire characteristic investigated via chemical composition, fired shrinkage, porosity, apparent porosity, bulk density and modulus of rupture. The clay can be used as a fired refractory, while silica, feldspar and ball clay could be used as a source of silica and alumina for ceramic products.

Adequate utilization of available natural resources in Nigeria such as clay, quartz, feldspar and ball clay will help in domesticating production of water closet.

\section{Conflicts of Interest}

The authors declare no conflicts of interest regarding the publication of this paper.

\section{References}

[1] Abiodun, S.O., Akintonde, M.A. and Akinde, T.E. (2013) Small Scale Ceramic Industry in Oyo State: Challenges and Prospects. Journal of Economics and Sustainable Development, 4, 103-111.

[2] Elakhame, Z.U., Ifebhor, F. and Asotah, W.A. (2016) Development and Production of Ceramic Tiles from Waste Bottle Powder (Milled Glass). Journal of Science, Engineering and Technology, 12, 50-59. https://doi.org/10.3126/kuset.v12i2.21521

[3] Elakhame, Z.U., Bello, S.A., Agunsoye, J.O., Patric, I. and Otitoju, O. (2016) Characterization of Ujogba Clay Deposits in Edo State, Nigeria for Refractory Applications. Journal of Science, Engineering and Technology, 12, 71-82. https://doi.org/10.3126/kuset.v12i2.21523

[4] Fowowe, M.O. (2004) Changing Phases of Tradition. CPAN Journal of Ceramics, 2, 11-16.

[5] Haulin, E.N., Nya, F.T., Kabe, C. and Touolak, B.T. (2014) Physic-Mechanical Characterization of Materials Clay Mayo-Tsanaga in the Far North Region of Cameroon. American Journal of Materials Science and Engineering, 2, 68-72. https://doi.org/10.12691/ajmse-2-4-4

[6] Nwajugu, C.O. and Aneke, L.E. (2001) Characterization of Ukpor Clay Deposit. Journal of Nigerian Society of Chemical Engineering, 5, 1-3, 11.

[7] Nosbusch, H. and Mitchell, I.V. (1998) Clay Based Materials for Ceramics Industry. Elsevier Science Publishing Company Inc., England, 4.

[8] Odinaka, A. (2014) Skill Gap, Processing Challenges Blight $\$ 465$ Million Nigeria Ceramic Industry an Internet Document. http://www.businessdayonline.com

[9] Araham, J. (2018) Investigating in Ceramics Glaze Materials Production. The Punch News Paper. https://punchng.com/

[10] Opoku, E.V. (2003) Development of Local Raw Materials for the Ceramics Industry in Nigeria. Ashakwu Journal of Ceramics, 1, 14-17.

[11] Swaby, R. (2012) Why Toilets Are Still Made of Porcelain-Gizmodo Australia. https://gizmodo.com/why-toilets-are-still-made-of-porcelain-5930537 
[12] Singer, F. and Singer, S.S. (1963) Industrial Ceramics. Chapman and Hall, London. https://doi.org/10.1007/978-94-017-5257-2

[13] Mine AYTAÇ, S. (2014) The Social and Technical Development of Toilet Design. http://library.iyte.edu.tr/tezler/master/endustriurunleritasarimi/T000465.pdf

[14] Smoot, T.W. (1961) Clay Minerals in the Ceramic Industries. Clays Clay Miner, 10, 309-317. https://doi.org/10.1346/CCMN.1961.0100126

[15] Shuaib-Babata, Y.L. (2016) Suitability of Cow Horn as Filler in an Epoxy Composite. Journal of Engineering and Technology, 1, 15-19. 